\title{
MENINGKATKAN PRESTASI BELAJAR MATEMATIKA DENGAN MENERAPKAN METODE BERVARIASI PADA SISWA KELAS 1 SD SEPONTI
}

\author{
Mahyan \\ Guru SDN 2 Seponti Kabupaten Kayong Utara \\ Email: mahyansdn2sepontijaya@gmail.com
}

\begin{abstract}
Abstrak
Keberhasilan pembelajaran matematika ditentukan oleh bagaimana guru merencanakan, melaksanakan dan menilai dan tujuan yang telah ditetapkan. Metematika berfungsi untuk mengembangkan kemampuan menghitung, mengukur, menurunkan menggunakan rumus matematika sederhana yang diperlukan dalam kehidupan sehari-hari melalui materi mengenal segi tiga, segi empat, dan lingkaran. Tujuan penelitian ini adalah untuk mengetahui apakah metode bervariasi dapat meningkatkan prestasi belajar mata pelajaran Matematika Kelas 1 semester II SDN 2 Seponti Jaya Kecamatan Seponti Kabupaten Kayong Utara. Berdasarkan hasil refleksi pada siklus 3 diketahui bahwa dalam proses pembelajaran menggunakan metode bervariasi ada 3 indikator yang belum berhasil dengan baik tetapi sudah terlaksana. Dari data yang dihimpun dari observasi pengamat didapatkan bahwa keberhasilan guru baru 10 indikator dari 13 indikator yang direncanakan, atau $77 \%$. Berdasarkan observasi didapatkan nilai rata-rata yang dicapai sisa adalah 71,7. Nilai tertinggi yang dicapai siswa adalah 9. Sedangkan nilai terendah yang dicapai siswa adalah 4. Siswa yang mendapat nilai dibawah 70 sejumlah 5 siswa yakni 17,85\%, yang mencapai nilai 70 ke atas sejumlah 23 siswa atau $82,12 \%$.
\end{abstract}

\section{Kata Kunci : Prestasi Belajar, Metode Bervariasi, Matematika}

\section{PENDAHULUAN}

Mata pelajaran matematika di sekolah dasar merupakan salah satu program pembelajaran yang bertujuan untuk mempersiapkan siswa agar sanggup menghadapi perubahan keadaan didalam kehidupan yang selalu berkembang, melalui latihan bertindak atas dasar pemikiran secara logis, rasional, kritis, cermat, jujur, dan efektif. Selain membina perubahan dan harapan kehidupan pada anak, juga mempersiapkan siswa agar menggunakan matematika dan pola pikir matematika dalam kehidupan seari hari, dan dalam mempelajari berbagai ilmu pengetahuan.

Pentingnya pembelajaran matematika disekolah dasar juga dituangkan dalam GBPP matematika SD, bahwa pengajaran matematika di SD dapat menumbuhkan dan mengembangkan keterampilan berhitung (Menggunakan Bilangan) sebagai alat dalam kehidupan sehari-hari. Keberhasilan pembelajaran matematika ditentukan oleh bagaimana guru merencanakan, melaksanakan dan menilai dan tujuan yang telah ditetapkan. Metematika berfungsi untuk mengembangkan kemampuan menghitung, mengukur, menurunkan menggunakan rumus matematika sederhana yang diperlukan dalam kehidupan sehari-hari melalui materi mengenal segi tiga, segi empat, dan lingkaran.

Salah satu tujuan pembelajaran matematika di SD adalah melatih cara berfikir dan bernalar dalam menarik kesimpulan, misalnya melalui kegiatan-kegiatan penyelidikan, eksplorasi, eksperimen, menunjukkan kesamaan, perbedaan, konsisten dan inkonsisten dan mengembangkan aktifitas kreatif yang melibatkan imajinasi, intuisi, dan penemuan dengan mengembangkan pemikiran divergen, orisinil, rasa ingin tahu, membuat prediksi dan dugaan, mencoba-coba serta kemampuan memecahkan masalah. Menurut Jean Peaget dan teman-temannya menunjukkan bahwa anak tidak bertindak dan berfikir sama seperti orang dewasa lebih-lebih dalam pembelajaran matematika di SD, suatu yang abstrak dapat saja dipandang sedrhana menurut kita yang sudah formal, namun dapat saja menjadi sesuatu yang sulit dimengerti oleh anak yang belum formal.

Apa yang dimaksud dengan Prestasi Belajar ? Sebelum dijelaskan mengenai prestasi belajar, terlebih dahulu akan dikemukakan tentang pengertian prestasi. Sudah dijelaskan dimuka bahwa yang dimaksud dengan prestasi 
adalah hasil yang telah dicapai. Dengan demikian prestasi adalah hasil yang telah dicapai oleh seseorang setelah melakukan suatu pekerjaan / aktivitas tertentu. Jadi prestasi adalah hasil yang telah dicapai oleh karena itu semua individu dengan adanya belajar hasilnya dapat dicapai. Setiap individu menginginkan hasil yang sebaik mungkin. Oleh karena itu setiap individu harus belajar dengan sebaik- baiknya supaya prestasinya berhasil dengan baik.

Pengertian dari dua kata prestasi dan belajar atau prestasi belajar berarti hasil belajar, secara lebih khusus setelah siswa mengikuti pelajaran dalam kurun waktu tertentu. Berdasarkan penilaian yang dilaksanakan guru di sekolah, maka prestasi belajar dituangkan atau diwujudkan dalam bentuk angka (kuantitatif) dan pernyataan verbal (kualitatif). Prestasi belajar yang dituangkan dalam bentuk angka misalnya 10, 9, 8, dan seterusnya. Sedangkan prestasi belajar yang dituangkan dalam bentuk pernyataan verbal misalnya, baik sekali, baik, sedang, kurang, dan sebagainya.

Menurut the Liang Gia (1989: 15) Mengatakan bahwa: Prestasi belajar adalah hasil yang dicapai aktifitas yang menghasilkan perubahan-perubahan tingkah laku dalam individu, baik secara aktual maupun profesional “. Sedangkan Purwodarminto (1987: 254), mengatakan bahwa : " prestasi belajar adalah suatu hasil yang dicapai atau dikerjakan siswa dalam belajar atau usaha untuk memperoleh suatu kepandaian ".

Belajar sangat erat hubungannya dengan prestasi belajar.Karena prestasi itu sendiri merupakan hasil belajar itu biasanya dinyatakan dengan nilai. Menurut Winarno Surahmad (1997 : 88) sebagai berikut: "Hasil belajar adalah hasil dimana guru melihat bentuk akhir dari pengalaman interaksi edukatif yang diperhatikan adalah menempatkan tingkah laku". Dapat diartikan bahwa hasil belajar adalah suatu bentuk pertumbuhan atau Perubahan diri seseorang yang dinyatakan dengan cara bertingkah laku baru berkatpengalaman baru.

Dari pengertian tersebut diatas dapat disimpulkan, bahwa prestasi belajar adalah suatu hasil belajar yang dicapai dalam aktifitas untuk mendapat suatu kepandaian atau sebuah tingkah laku yang lebih baik.

Untuk memperoleh prestasi belajar atau hasil belajar yang baik harus dilakukan dengan pedoman cara yang tepat. Setiap orang mempunyai cara atau pedoman sendiri- sendiri dalam belajar. Pedoman atau cara yang satu cocok digunakan oleh seorang siswa, tetapi belum tentu cocok untuk siswa yang lain. Hal ini disebabkan karena mempunyai perbedaan individu dalam hal kemampuan, kecepatan dan kepekaan dalam menerima materi pelajaran. Oleh karena itu tidaklah ada suatu petunjuk yang pasti yang harus dikerjakan oleh seorang siswa dalam melakukan kegiatan belajar. Tetapi faktor yang paling menentukan keberhasilan belajar adalah para siswa itu sendiri. Untuk dapat mencapai hasil belajar yang sebaik- baiknya harus mempunyai kebiasaan belajar yang baik.

Banyak sekali Faktor- Faktor Yang Mempengaruhi Prestasi Belajar Telah dikatakan dimuka bahwa belajar adalah berusaha memperoleh kepandaian, ilmu pengetahuan. Sampai dimanakah perubahan itu dapat dicapai atau dengan kata lain dapat berhasil baik atau tidaknya belajar itu tergantung pada macammacam faktor. Adapun faktor- faktor itu, dapat dibedakan menjadi dua golongan yaitu: 1) Faktor yang ada pada diri siswa itu sendiri yang kita sebut faktor individu. 2) Faktor yang ada pada luar individu yang kita sebut dengan faktor sosial.

Berdasarkan faktor yang mempengaruhi kegiatan belajar di atas menunjukkan bahwa belajar itu merupakan proses yang cukup kompleks. Aktivitas balajar individu memang tidak selamanya menguntungkan. Kadangkadang juga tidak lancar, kadang mudah menangkap apa yang dipelajari, kadang sulit mencerna materi pelajaran. Dalam keadaan dimana anak didik atau siswa dapat belajar sebagaimana mestinya, itulah yang disebut kesulitan belajar. Dalam kondisi Seperti itu maka di perlukan metode atau starategi belajar untuk mencapai prestasi belajar yang maksimal.

Dalam kajian ini akan dibahas tentang Metode bervariasi yang akan digunakan dalam proses perbaikan pembelajaran. Dalam proses pembelajaran Matematika ini metode yang akan dibuat untuk memperbaiki proses belajar mengajar adalah Metode bervariasi. Yang di maksud dengan metode bervariasi adalah penggunaan beberapa metode pembelajaran yang digunakan dalam satu proses pembelajaran. Dalam penelitian ini peneliti menggunakan gabungan beberapa metode pembelajaran antara lain yaitu 1). Direct Instruction (Pembelajaran langsung) 2). Cooperatif Learning (Pembelajaran berbasis kelompok) dan 3) Problem Base learning 
(Pembelajaran berbasis masalah).

Yang dimaksud dengan Direct Instruction atau Pembelajaran langsung adalah metode pembelajaran yang mengutamakan siswa mempunyai pengalaman langsung dengan mengerjakan sendiri dalam belajar. Siswa secara langsung memperhatikan demontrasi kegiatan belajar yang dilakukan oleh guru dan secara langsung diikuti oleh siswa secara ber ulang ulang sampai pada tahapan siswa dapat mengerjakan sendiri tanpa bantuan guru.

Metode yang kedua adalah cooperative Learning atau pembelajaran berbasis kelompok yaitu strategi pembelajaran yang menekankan pada sikap atau prilaku bersama dalam bekerja atau membantu diantara sesama dalam struktur kerja sama yang teratur di dalam kelompok yang terdiri dari dua atau lebih siswa. Metode yang kedua adalah Metode Problem based learning atau pembelajaran berbasis masalah. Yaitu strategi pembelajaran yang mengutamakan kemampuan siswa dalam menyelesaikan masalah baik secara individu maupun berkelompok. Menurut Soegito dan Nurani (2002), penggunaan metode mengajar yang bervariasi dapat meningkatkan minat siswa untuk mengikuti pelajaran, sehingga akan menigkatkan prestasi belajar.

Dengan kombinasi beberapa metode pembelajaran tersebut maka perbaikan pembelajaran dalam penelitian ini dinamakan Metode Bervariasi. Untuk menetapkan jenis metode apa yang akan dikombinasikan dalam proses belajar mengajar disesuaikan dengan jenis materi yang akan di sampaikan. Dalam proses perbaikan pembelajaran matematika ini peneliti menetapkan tiga strategi pembelajaran yaitu Direct Instuction, Cooperatif Learning, dan Problem Based learning.

Dalam penelitian ini peneliti merujuk pada penelitian yang sudah dilakukan oleh beberapa tenaga pendidikan yang menggunakan metode variasi dalam perbaikan pembelajaran salah satunya adalah Novita (2006) di SMA Negeri 2 Padang Panjang Kelas XI, dalam penelitian tindakan kelas tersebut disimpulkan bahwa Penggunaan metode variasi akan meningkatkan minat dan motivasi belajar sehingga akan meningkatkan prestasi belajar.

Berdasarkan beberapa rujukan penelitian tersebut maka, peneliti bermaksud mengadakan penelitian tindakan kelas dengan menggunakan metode bervariasi untuk memperbaiki prestasi siswa SDN Seponti 01 Kelas I Kecamatan
Seponti Kabupaten Kayong Utara. Pada bidang studi Matematika.

Proses belajar yang dilakukan oleh para pendidik sebagian besar dilakukan dengan mengunakan metode ceramah, hal ini dilakukan karena guru karena merasa tidak ingin direpotkan dan memilih cara mudah dalam menyampaikan materi pelajaran, namun hal itu sangat merugikan siswa sebagai pihak yang menerima informasi atau objek yang akan menerima materi pelajaran.

Dalam proses pembelajaran modern strategi mempunyai posisi penting dalam menghasilkan prestasi belajar karena setiap materi yang disampaikan mempunyai karakteristik yang berbeda, suatu contoh materi pelajaran eksak sangat berbeda karakteristiknya dengan materi sosial sebab materi Matematika atau eksak cenderung menekankan pada masalah psikomotorik. Jika materi yang demikian sangatlah tidak sesuai jika seorang pendidik menggunakan strategi pembelajaran yang konvensional yaitu mengunakan metode ceramah karena cara tersebut tidak memberikan pemahaman yang baik terhadap siswa karena siswa cenderung diajak berfantasi saja. Berbeda jika seorang pendidikan menggunakan berbagai macam kombinasi metode pembelajaran, contoh metode ceramah, metode Cooperatif, metode problem based instruction dan sebagaiannya. Kombinasi berbagai macam metode membuka gerak dan kreatifitas bagi pendidik untuk meningkatkan prestasi belajar melalui berbagai macam metode untuk menghindarkan kejenuhan dan kebosanan bagi siswa. Berdasarkan argumen itulah maka, peneliti menentukan metode perbaikan pembelajaran bidang studi matematika untuk kelas I di SDN 2 Seponti Jaya Kecamatan Seponti Kabupaten Kayong Utara.

\section{METODE PENELITIAN}

Pelaksanan perbaikan pembelajaran siklus I sampai dengan siklus III dilaksanakan di SDN 2 Seponti Jaya Kecamatan Seponti Kab. Kayong Utara tanggal 15 April sampai 17 April 2018. Sedangkan subjek penelitian adalah Siswa Kelas I SDN 2 Seponti Jaya pada semester Genap Tahun 2018 Berjumlah 28 Siswa. Adapun secara rinci jadwal pelaksanaan pembelajaran untuk mata pelajaran Matematika tentang pengenalan bangun datar yaitu segitiga, persegi dan lingkaran : (1) Siklus I dilaksanakan tanggal 1 April 2018 dengan waktu 2 jam pelajaran (1 x 35 menit). (2) Siklus II dilaksanakan tanggal 8 
April 2018 dengan waktu 2 jam pelajaran ( $1 \mathrm{x}$ 35 menit). (3) Siklus III dilaksanakan tanggal 15 April 2018 dengan waktu 2 jam pelajaran ( 1 x 35 menit)

Rencana perbaikan pembelajaran pada laporan ini meliputi 3 siklus. Rencana perbaikan pembelajaran Matematika yang dimaksud adalah pengenalan bangun datar yaitu segitiga, persegi dan lingkaran melalui metode bervariasi. Adapun perencanaan perbaikan pembelajaran sebagai

berikut:

Tabel 1. Rencana Pelaksanaan Tindakan Perbaikan

\begin{tabular}{clcc}
\hline Tahap & Fokus & Kegiatan guru & Kegiatan siswa \\
\hline Kegiatan awal & Memotivasi & Membuka & Merespon apa \\
& siswa dan & pelajaran & disampaikan guru. \\
& apersepsi & Mengaitkan & Menjawab pertanyaan guru. \\
& topik dengan & Memperhatikan penjelasan \\
& pengetahuan awal & guru. & Memperhatikan penjelasan \\
& siswa dengan cara & guru tentang tujuan dan langkah- \\
& tanya jawab. & Menyampaikan & langkah pembelajaran yang akan \\
& tujuan dan langkah- & diikuti oleh siswa \\
& langkah & \\
& pembelajaran. \\
& Menyampaikan \\
& gambaran inti \\
& pembelajaran.
\end{tabular}

\begin{tabular}{|c|c|c|c|}
\hline $\begin{array}{l}\text { Kegiatan inti } \\
\text { Pembelajaran }\end{array}$ & $\begin{array}{l}\text { Meningkatkan } \\
\text { kemampuan } \\
\text { pengenalan } \\
\text { bangun datar } \\
\text { yaitu segitiga, } \\
\text { persegi dan } \\
\text { lingkaran }\end{array}$ & $\begin{array}{l}\text { Guru } \\
\text { menjelaskan tentang } \\
\text { perkalian dan } \\
\text { pembagian. } \\
\text { Memberi } \\
\text { kesempatan siswa } \\
\text { untuk bertanya } \\
\text { jawab. } \\
\quad \text { Secara } \\
\text { kelompok siswa } \\
\text { mengerjakan LKS. } \\
\quad \text { Guru } \\
\text { membimbing siswa } \\
\text { untuk menyamakan } \\
\text { persepsi. } \\
\text { Guru memberi } \\
\text { tugas secara } \\
\text { individu. }\end{array}$ & $\begin{array}{l}\text { Memperhatikan- kan } \\
\text { penjelasan guru. } \\
\text { Siswa bertanya dan dijawab } \\
\text { atau direspon siswa yang lain. } \\
\text { Siswa berkelompok } \\
\text { mengerjakan LKS } \\
\text { Secara kelompok } \\
\text { Menyampaikan hasil diskusi dan } \\
\text { Menanggapi kelompok lain. } \\
\text { Siswa melaksanakan tugas } \\
\text { dari guru }\end{array}$ \\
\hline Kegiatan Akhir & $\begin{array}{l}\text { Memantapkan } \\
\text { pemahaman } \\
\text { siswa. } \\
\text { Tindak lanjut }\end{array}$ & $\begin{array}{l}\text { Guru } \\
\text { menyimpulkan } \\
\text { materi pelajaran } \\
\text { Mengevaluasi } \\
\text { kemampuan siswa. } \\
\text { Menugasi siswa } \\
\text { mengerjakan } \\
\text { bangun datar yaitu } \\
\text { segitiga, persegi dan } \\
\text { lingkaran }\end{array}$ & $\begin{array}{l}\text { Siswa memperhatikan dan } \\
\text { mencatat hasil kesimpulan. } \\
\text { Secara individu siswa } \\
\text { mengerjakan tes formatif. } \\
\text { Menilai sendiri hasil tes } \\
\text { pemahamannya dengan } \\
\text { bimbingan guru. } \\
\text { Siswa mengerjakan tugas } \\
\text { dirumah. }\end{array}$ \\
\hline
\end{tabular}


Dalam tahap pelaksanaan pada siklus I sampai dengan siklus III diamati dengan seorang supervisor dan 2 orang pengamat sebagai mitra atau teman sejawat. Dipilihnya orang pengamat ini karena keduanya sama-sama melaksanakan perbaikan pembelajaran sehingga sudah saling memahami tugasnya sebagai pengamat. Selama pelaksanaan tindakan teman sejawat melaksanakan pengamatan mulai percobaan pelaksanaan awal sampai akhir pembelajaran dan hasil pembelaji.ran setiap siklusnya. Pengamat melakukan pencatatan dan pengamatan pada tindakan, dibagi menjadi tiga tahap yakni tahap awal, tahap inti, dan tahap akhir pembelajaran. Pencatatan dilakukan pada lembar observasi yang sudah dipersiapkan sebelumnya.

Pelaksanaan yang ditempuh dalam perbaikan pembelajaran Matematika tentang perkalian dan pembagian bilangan pada siklus 1 adalah sebagai berikut. Kegiatan guru pada tahap awal, adalah 1. Membuka pelajaran, 2. Mengaitkan topik dengan pengetahuan awal siswa dengan eara tanya jawab, 3. Menyampaikan tujuan dan langkah-langkah pembelajaran, 4. Menyampaikan tujuan inti pembelajaran. Adapun kegiatan siswa adalah 1 . Merespon apa yang disampaikan guru, 2. Menjawab pertanyaan guru, 3. Memperhatikan penjelasan tenta'ng tujuan dan langkah-langkah pembelajaran yang akan diikuti, 4. Memperhatikan penjelasan guru menyampaikan gambaran init pembelajaran.

Tindakan guru pada kegiatan inti adalah : 1) Guru menjelaskan tentang pengenalan bangun datar yaitu segitiga, persegi dan lingkaran. 2) Memberi kesempatan siswa untuk bertanya dan. 3 ) Secara kelompok siswa mengamati bangun datar yaitu segitiga, persegi dan lingkaran pengenalan bangun datar yaitu segitiga, persegi dan lingkaran yang disediakan guru dengan mengerjakan LKS. 4 ) Guru membimbing siswa untuk menyamakan persepsi hasil pekerjaan LKS nya. 5 ) Secara individual siswa mengerjakan soal bangun datar yaitu segitiga, persegi dan lingkaran di papan tulis. 6 ) Bersama siswa menyimpulkan materi pelajaran. Sebalikya, kegiatan siswa pada kegiatan inti adalah: 1) Siswa Menyimak dan memperhatikan penjelasan guru. 2) Siswa bertanya dan dijawab atau direspon oleh siswa yang lain. 3) Siswa berkelompok dan mengerjakan LKS. 4) Secara kelompok menyampaikan hasil diskusi dan ditanggapi kelompok lain. 5) Secara individu siswa melaksanakan tugas guru. 6) Siswa memperhatikan dan mencatat hasil kesimpulan.

Tindakan guru pada kegiatan akhir adalah:

1) Mengevaluasi kemampuan siswa. 2) Menugasi siswa soal pengenalan bangun datar yaitu segitiga, persegi dan lingkaran. Sebaliknya kegiatan siswa pada tahap akhir adalah: 1) Secara individu siswa mengerjakan tes formatif. 2) Dengan bimbingan guru siswa menilai sendiri hasil tes pernahamannya tentang bangun datar yaitu segitiga, persegi dan lingkaran. 3) siswa mengerjakan tugas di rumah.

Penerapan metode bervariasi pada kegiatan awal tampak pada saat guru mengadakan apersepsi dengan cara bertanya jawab mengaitkan topik dengan pengetahuan awal siswa dengan pertanyaan " Apa bangun datar itu ?". Apa segitiga itu ?. Siswa tampak malas menjawab, hanya 6 orang yang mengacungkan tangannya. Meskipun guru mengulang pertanyaan sampai tiga kali siswa yang mengacungkan tangannya hanya tambah satu siswa. Kegiatan berikutnya guru menjelaskan tujuan namun langkah- langkah pembelajaran belum disampaikan, dan menyampaikan gambaran inti pembelajaran. Siswa tampak memperhatikan dan antusias.

Pelaksanaan tindakan pada kegiatan inti ini waktunya kurang. Dimulai dengan memajangkan alat peraga pengenalan bangun datar yaitu segitiga, persegi dan lingkaran dipapan tulis. Pelaksanaan tindakan pada kegiatan akhir, siswa secara individu mengerjakan tes formatif. Siswa tampak tergesagesa karena waktunya memang sudah habis, dan menginjak waktu istirahat. Sehingga kegiatan menilai pekerjaan sendiri belum terlaksana. Demikian juga tugas untuk pengenalan bangun datar yaitu segitiga, persegi dan lingkaran sebagai tindak lanjut belum terlaksana.

Dari proses pengamatan teman sejawat (observer) mengamati guru sebagai peneliti dan siswa sebagai subjek didapatkan data data yang bersifat kwalitatif maupun kuantitatif. Adapun aspek yang diamati adalah keterlibatan guru dan siswa selama proses pembelajaran yang meliputi kegiatan awal, kegiatan inti. dan kegiatan akhir dan hasil tes.

Sebagaimana yang dijelaskan di depan bahwa hasil pengamatan pada tahap kegiatan awal yang belum berhasil adalah pelaksanaan tanya jawab kurang merata, penjelasan langkahlangkah pembelajaran perlu disampaikan.

Pada tahap kegiatan inti indikator yang 
belum berhasil adalah alat peraga yang dipajang dipapan tulis tidak ada judul, kegiatan bertanya jawab, diskusi kelompok, kegiatan penyamaan persepsi, dan kegiatan individual mengerjakan pengenalan bangun datar yaitu segitiga, persegi dan lingkaran ke depan indikator tersebut sudah terlaksana namun belum berhasil.

Untuk kegiatan akhir menilai pekerjaan sendiri dan mengerjakan pengenalan bangun datar yaitu segitiga, persegi dan lingkaran sebagai tindak lanjut belum terlaksana karena waktunya habis. Dari hasil oiskusi ada 9 indikator yang belum berhasil. Sehingga dapat dikatakan baliwa keberhasilan guru baru 4 indikator dari 13 indikator yang direncanakan, atau $36 \%$. Adapun keberhasilan siswa dalam tes formatif sebagaimana dipaparkan berikut ini.

\section{HASIL DAN PEMBAHASAN PENELITIAN Hasil Penelitian}

Dari paparan data dapat dijelaskan bahwa nilai rata-rata yang dicapai siswa adalah 54,2 Nilai tertinggi yang dicapai siswa adalah 80, sehingga nilai terendah yang dicapai siswa adalah 3. Siswa yang mendapat nilai dibawah 70 sejumlah 21 siswa yakni $75 \%$, Yang mencapai nilai 60 keatas sejumlah 7 siswa yakni $25 \%$. Agar semua siswa mau menjawab guru perlu memberi penguatan dan memberi saran pada siswa untuk berlatih mengungkapkan gagasannya, jika pertanyaannya salah akan dibantu memperbaikinya. Demikian juga penjelasan langkah-langkah pembelajaran perlu disampaikan, karena siswa akan tahu kegiatan berikutnya tanpa menunggu informasi dari guru.

Pada kegiatan inti pembelajaran ada beberapa indikator yang belum berhasil yakni: kegiatan memajangkan alat peraga bangun datar yaitu segitiga, persegi dan lingkaran dipapan tulis. Agar siswa tidak menggerombrol di depan papan tulis, Guru sebaiknya menyediakan fotokopi bangun datar yaitu segitiga, persegi dan lingkaran sehingga sebelum ditugasi mengerjakan bangun datar yaitu segitiga, persegi dan lingkaran siswa bisa mengamati ditempat duduknya. Demikian juga pada saat anak diberi kesempatan bertanya dan menjawab pertanyaan temannya kurang berhasil karena hanya beberapa anak yang mau bertanya. Agar semua siswa mau bertanya dan menjawab pertanyaan temannya karena belum terbiasa, sebaiknya diberi kesempatan untuk menuliskan pertanyaan atau jawaban pertanyaan teman. Pada saat kerja kelompok sebaiknya sebelum mulai dijelaskan perlunya kerja kelompok dan pembagian tugas dari masing-masing kelompok. Saat siswa ditugasi menunjuk agar siswa siap menunjuk pada bangun datar yaitu segitiga, persegi dan lingkaran di papan tulis. siswa diberi kesempatan mengamati perkalian dan pembagian yang dibagikan sebelumnya sehingga siswa tidak takut salah.

Untuk kegiatan akhir menilai sendiri hasil tes perlu dilaksanakan karena selain melatih kejujuran siswa juga akan mengurangi tugas guru apabila siswa sudah terlatih. Waktu yang digunakan untuk siklus 1 ini sampai terlambat 20 menit karena anak terbiasa menerima penjelasan dari guru.

Berdasarkan hasil refleksi pada siklus I maka buat rencana perbaikan pembelajaran siklus II melalui metode bervariasi. Adapun perencanaan perbaikan pembelajaran sebagai berikut:

Tabel 3. Rencana Pelaksanaan Tindakan Perbaikan

\begin{tabular}{cllc}
\hline Tahap & \multicolumn{1}{c}{ Fokus } & Kegiatan guru & Kegiatan siswa \\
\hline Kegiatan awal & Memotivasi & Membuka & Merespon apa yang \\
& siswa dan & pelajaran & disampaikan guru. \\
& apersepsi & Mengaitkan & Menjawab pertanyaan guru. \\
& topik dengan & Memperhatikan penjelasan \\
& pengetahuan awal & guru. \\
& siswa dengan cara & Memperhatikan penjelasan \\
& tanya jawab. & guru tentang tujuan dan \\
& Menyampaikan & langkah-langkah pembelajaran \\
& tujuan dan langkah- & yang akan diikuti oleh siswa \\
& langkah & \\
& pembelajaran. & \\
& Menyampaikan & \\
& gambaran inti & \\
& pembelajaran. & \\
& &
\end{tabular}




\begin{tabular}{|c|c|c|c|}
\hline $\begin{array}{l}\text { Kegiatan inti } \\
\text { Pembelajaran }\end{array}$ & $\begin{array}{l}\text { Meningkatkan } \\
\text { kemampuan } \\
\text { tentang } \\
\text { bangun datar yaitu } \\
\text { segitiga, persegi dan } \\
\text { lingkaran }\end{array}$ & $\begin{array}{l}\text { Guru } \\
\text { menjelaskan } \\
\text { tentang perkalian } \\
\text { dan pembagian. } \\
\text { Memberi } \\
\text { kesempatan siswa } \\
\text { untuk bertanya } \\
\text { jawab. } \\
\text { Secara kelompok } \\
\text { siswa mengerjakan } \\
\text { LKS. } \\
\text { Guru } \\
\text { membimbing siswa } \\
\text { untuk menyamakan } \\
\text { persepsi. } \\
\text { Guru memberi } \\
\text { tugas secara } \\
\text { individu. }\end{array}$ & $\begin{array}{l}\text { Memperhatikan- kan } \\
\text { penjelasan guru. } \\
\text { Siswa bertanya dan dijawab } \\
\text { atau direspon siswa yang lain. } \\
\text { Siswa berkelompok } \\
\text { mengerjakan LKS } \\
\text { Secara kelompok } \\
\text { Menyampaikan hasil diskusi } \\
\text { dan Menanggapi kelompok lain. } \\
\text { Siswa melaksanakan tugas } \\
\text { dari guru }\end{array}$ \\
\hline Kegiatan Akhir & $\begin{array}{l}\text { Memantapkan } \\
\text { pemahaman } \\
\text { siswa. } \\
\text { Tindak lanjut }\end{array}$ & $\begin{array}{l}\text { Guru } \\
\text { menyimpulkan } \\
\text { materi pelajaran } \\
\quad \text { Mengevaluasi } \\
\text { kemampuan siswa. } \\
\quad \text { Menugasi siswa } \\
\text { mengerjakan } \\
\text { operasi bangun } \\
\text { datar yaitu segitiga, } \\
\text { persegi dan } \\
\text { lingkaran }\end{array}$ & $\begin{array}{l}\text { Siswa memperhatikan dan } \\
\text { mencatat hasil kesimpulan. } \\
\text { Secara individu siswa } \\
\text { mengerjakan tes formatif. } \\
\text { Siswa mengerjakan tugas } \\
\text { dirumah. }\end{array}$ \\
\hline
\end{tabular}

Penerapan metode bervariasi pada kegiatan awal tampak pada saat guru mengadakan apersepsi dengan cara bertanya jawab mengaitkan topik dengan pengetahuan awal siswa dengan pertanyaan. " Kalian tentunya masih ingat inti pembelajaran minggu lalu. Jawabiah pertanyaan berikut ini, dengan cara mengacungkan tangan. Apa yang dimaksud dengan segitiga ?. Siswa tampak berebut akan menjawab, saya bu, saya bu sambil mengacungkan tangan. Guru menunjuk siswa yang akan mengacungan tangan paling awal. Guru tampak mengamati siswa yang mengacungkan tangan lebih dahulu. Guru mengacungkan ibu jarinya ketika siswa menjawab benar, untuk penguatan, dan tampaknya memotivasi siswa untuk menjawab pertanyaan secara lisan. Kegintan berikutnya guru menjelaskan tujuan dan langkah-langkah pembelajaran dan menyampaikan gambaran inti pembelajaran. Siswa tampak memperhatikan, terlihat dari komentar anak " setelah ini diskusi atau mengerjakan bangun datar yaitu segitiga, persegi dan lingkaran, bu".

persegi dan lingkaran, siswa sudah tampak berani. Hai ini guru menggunakan strategi pertanyaan dibacakan, siswa mengamati contoh perkalian dan pembagian yang dipegangnya, bila sudah ketemu mengacungkan tangan. Kegiatan inti diakhiri dengan menyimpulkan materi pembelajaran, di sini siswa memperhatikan.

Pelaksanaan pada tindakan kegiatan akhir, siswa secara individu mengerjakan tes formatif. Siswa tampak aktif sesuai dengan waktu yang direncanakan. Selanjutnya siswa dibimbing untuk menilai sendiri hasil tesnya. Disini siswa ramai karena belum terbiasa dan setiap ada perbedaan jawaban meskipun maksudnya sama selalu ditanyakan kepada guru, sehingga belum tuntas dan guru masih harus memeriksa lagi. Sebagai tindak lanjut guru menugasi siswa mengerjakan soal bangun datar yaitu segitiga, persegi dan lingkaran.

Keberhasilan tindakan ini berdasarkan hasil 
pengamatan selama pelaksanaan tindakan dan sesudah tindakan dilaksanakan. Teman sejawat mengamati perilaku selama guru dan siswa. Adapun aspek yang diamati adalah keterlibatan guru dan siswa selama proses pembelajaran yang meliputi kegiatan awal, kegiatan inti, dan kegiatan akhir.

Berdasarkan diskusi hasil pengamatan, tindakan pada tahap kegiatan awal ini yang belum berhasil adalah penjelasan langkahlangkah pembelajaran, Penjelasan lankahlangkah pembelajaran belum disampaikan secara rinci dan jelas. Ini tampak setiap kali selesai satu langkah kegiatan siswa masih diam menunggu perintah dari guru.

Pada tahap kegiatan inti indikator yang belum berhasil adalah kegiatan bertanya jawab, baru sekitar $50 \%$ siswa yang aktif terlibat. Diskusi kelompok, kegiatan pcnyamaan persepsi.Untuk kegiatan akhir tindakan yang belum berhasil adalah kegiatan siswa menilai pckerjaan sendiri. Dari hasil diskusi ada 5 indikator yang belum berhasil. Sehingga dapat dikatakan bahwa keberhasilan guru barn 9 indikator dari 13 indikator yang direncanakan, atau $69,2 \%$.

Adapun keberhasilan siswa dalam tes formatif sebagaimana dipaparkan berikut ini. Dari data tersenbut dapat dijelaskan nilai ratarata yang dicapai siswa adalah 61,7. Nilai tertinggi yang dicapai siswa adalah 9, sedangkan nilai terendah yang dicapai siswa adalah 3 . Siswa yang mendapat nilai dibawah 70 sejumlah 11 orang yakni $39,29 \%$, yang mencapai nilai 70 ke atas sejumlah 17 atau $60,71 \%$.

Agar semua siswa aktif dan tidak selalu menunggu perintah guru, penjelasan langkahlangkah pcmbelajaran perlu disampaikan, agar siswa tahu kegiatan berikutnya tanpa menunggu informasi dari guru. Pada kegiatan inti pembelajaran ada beberapa indikator yang belum berhasil yakni: pada saat anak diberi kesempatan bertanya dan menjawab pertanyaan temannya belum semua anak aktif. Agar semua aktif sebaiknya bagi anak yang sulit mengungkapkan pertanyaan secara langsung disarankan bagi yang tidak bertanya, tugasnya menjawab pertanyaan temannya. Pada saat kerja kelompok pembagian tugas dari masing-masing anggota kelompok perlu ditegaskan. Yang menjadi ketua perlu dicatat oleh guru sehingga saat melaporkan hasil tidak saling menunjuk sehingga langkah ini waktunya panjang.

Untuk kegiatan akhir menilai sendiri hasil tes perlu dilaksanakan karena selain melatih kejujuran siswa juga akan mengurangi tugas guru apabila siswa sudah terbiasa melakukannya. Watu yang dipakai untuk tindakan siklus 2 sudah sesuai dengan rancangan, tepat 70 menit.

Dengan memperhatikan refleksi siklus kedua penulis melakukan tindakan perbaikan pembelajaran Matematika tentang bangun datar yaitu segitiga, persegi dan lingkaran pada siklus III. Adapun pelaksanaaanya sebagaimana berikut ini. Kegiatan guru pada tahap awal, adalah 1) Membuka pelajaran. 2) Mengaitkan topik dengan pengetahuan awal siswa dengan tanya jawab. 3) Menyampaikan tujuan dan langkah-langkah pembelajaran.

Menyampaikan tujuan inti pembelajaran. Adapun kegiatan awal siswa adalah: 1) Merespon apa yang disampaikan guru. 2) Menjawab pertanyaan guru. 3) Memperhatikan penjelasan tentang tujuan dan langkah-langkah pembelajaran yang akan diikuti. 4) Memperhatikan penjelasan guru menyampaikan gambaran inti pembelajaran.

Tindakan perbaikan pada kegiatan inti adalah: 1) Memajangkan gambar bangun bangun datar yaitu segitiga, persegi dan lingkaran pada papan tulis. 2) Menugasi siswa menyimak penjelasan guru tentang bangun datar yaitu segitiga, persegi dan lingkaran 3) Memberi kesempatan pada siswa untuk bertanya dan mcnjawab. 4) Secara kelompok siswa mengamati bangun datar yaitu segitiga, persegi dan lingkaran dengan mengerjakan LKS. 5) Guru membimbing siswa untuk menyamakan persepsi hasil pekerjaan LKS nya. 6) Secara individual siswa menunjukkan bangun datar yaitu segitiga, persegi dan lingkaran. 7) Guru menyimpulkan materi pelajaran. Sebaliknya, kegiatan siswa pada tahap inti adalah: 1) Siswa memperhatikan bangun datar yaitu segitiga, persegi dan lingkaran. 2) Menyimak penjelasan guru. 3) Siswa bertanya dan dijawab atau direspon siswa yang lain. 4) Siswa berkelompok mengerjakan LKS sambil mengamati bangun datar yaitu segitiga, persegi dan lingkaran. 5) Secara kelompok menyampaikan hasil diskusi dan ditanggapi kelompok lain. 6) Secara individu siswa mclaksanakan tugas guru. 7) Siswa memperhatikan.

Tindakan guru pada kegiatan akhir adalah: 1) Mengevaluasi kemampuan siswa. 2) Menugasi siswa menggambar bangun datar yaitu segitiga, persegi dan lingkaran. Sebaliknya 
kegiatan siswa pada tahap akhir adalah: 1) Secara individu siswa mengerjakan tes formatif. 2) Dengan bimbingan guru siswa menilai sendiri hasil tes pemahamannya tentang bangun datar yaitu segitiga, persegi dan lingkaran. 3) Menggambar bangun datar yaitu segitiga, persegi dan lingkaran tindak lanjut.

Penerapan metode bervariasi pada kegiatan awal tampak pada saat guru mengadakan apersepsi dengan cara bertanya jawab mengaitkan topik dengan pengetahuan awal siswa dengan pertanyaan. Guru menunjuk siswa yang mengacungkan tangan paling lama. Guru penguatan dengan mengatakan bagus, pinter, sebagai penguat.Siswa tampak termotivasi dan sebagian besar aktif untuk menjawab pertanyaan. Kegiatan berikuttnya guru menjelaskan tujuan dan langkah-langkah pembelajaran. Penjelasan langkah-langkah ini disampaikan secara tegas dan tampak murid memahami. Menyampaikan gambaran inti pembelajaran terlaksana dengan baik.

Keberhasilan tindakan ini berdasarkan hasil pengamatan selama pelaksanaan tindakan dan scsudah tindakan dilaksanakan. Teman sejawat mengamati perilaku selama guru dan siswa. Adapun aspek yang diamati adalah keterlibatan guru dan siswa selama proses pembelajaran yang meliputi kegiatan awal, kegiatan inti, dan kegiatan akhir.

Berdasarkan diskusi hasil pengamatan, tindakan pada tahap . kegiatan awal ini sudah telaksana dengan baik. Tiga indikator terlaksana. Pada tahap kegiatan inti indicator yang belum berhasil adalah kegiatan diskusi kelompok dan penyamaan persepsi hasil diskusi belum terlaksana dengan baik. Untuk kegiatan akhir tindakan yang beium berhasil adalah kegiatan siswa menilai pekerjaan sendiri.

Dari hasil diskusi ada 3 indikator yang belum berhasil dengan baik tetapi sudah terlaksana. Sehingga dapat dikatakan bahwa keberhasilan guru baru 10 indikator dari 13 indikator yang direncanakan, atau $77 \%$.

Adapun keberhasilan siswa dalam tes formatif sebagaimana dipaparkan berikut ini. Dari paparan data tersebut dapat dijelaskan bahwa nilai rata-rata yang dicapai sisa adalah 71,70. Nilai tertinggi yang dicapai siswa adalah 9. sedangkan nilai terendah yang dicapai siswa adalah 4. Siswa yang mendapat nilai dibawah 70 sejumlah 5 siswa yakni 17,85\%, yang mencapai nilai 70 keatas sejumlah 23 siswa atau 82,12\%. Waktu yang digunakan pada siklus ketiga ini 70 menit, dan sisa waktu yang ada digunakan siswa untuk memperbaiki pengenalan segitiga, persegi dan lingkaran sebagai tindak lanjut.

Kegiatan pembelajaran ini secara umum sudah terlaksana, meskipun ada tiga indikator yang belum (terlaksana dengan baik. Untuk tiga indikator ini akan penulis tindak lanjuti ada kegiatan pembelajaran sehari-hari untuk yang akan datang. Demikian juga saat menilat sendiri hasil tesnya agar siswa biasa menilai tanpa bertanya, dijelaskan untuk jawaban yang sama besamya maupun yang jelas salah tidak perlu ditanyakan.

\section{Pembahasan Penelitian}

Berdasarkan hasil diskusi antara penulis, pengamat dan supervisor, setelah penyajian materi pada siklus ke 1, siklus ke-2, dan Ke-3 diperoleh data sebagai berikut :

Tabel 6. Hail Tes Formatif Siklus I, II, dan III

\begin{tabular}{ccccc}
\hline No & Kode Siswa & $\begin{array}{c}\text { Nilai } \\
\text { Siklus I }\end{array}$ & $\begin{array}{c}\text { Nilai } \\
\text { Siklus II }\end{array}$ & $\begin{array}{c}\text { Nilai } \\
\text { Siklus III }\end{array}$ \\
\hline 1. & S-1 & 50 & 70 & 70 \\
\hline 2 & S-2 & 30 & 30 & 80 \\
\hline 3 & S-3 & 60 & 80 & 80 \\
\hline 4 & S-4 & 70 & 70 & 70 \\
\hline 5 & S-5 & 50 & 50 & 90 \\
\hline 6 & S-6 & 80 & 80 & 40 \\
\hline 7 & S-7 & 40 & 40 & 70 \\
\hline 8 & S-8 & 70 & 70 & 90 \\
\hline 9 & S-9 & 50 & 80 & \\
\hline
\end{tabular}




\begin{tabular}{|c|c|c|c|c|}
\hline 10 & S-10 & 70 & 70 & 70 \\
\hline 11 & $S-11$ & 40 & 70 & 70 \\
\hline 12 & S-12 & 40 & 40 & 40 \\
\hline 13 & S-13 & 70 & 70 & 70 \\
\hline 14 & S-14 & 40 & 40 & 40 \\
\hline 15 & S-15 & 70 & 90 & 90 \\
\hline 16 & S-16 & 40 & 70 & 70 \\
\hline 17 & S-17 & 60 & 60 & 90 \\
\hline 18 & S-18 & 60 & 70 & 70 \\
\hline 19 & S-19 & 70 & 70 & 70 \\
\hline 20 & S-20 & 60 & 70 & 90 \\
\hline 21 & S-21 & 40 & 40 & 40 \\
\hline 22 & S-22 & 60 & 80 & 90 \\
\hline 23 & S-23 & 40 & 40 & 40 \\
\hline 24 & S-24 & 60 & 70 & 90 \\
\hline 25 & S-25 & 50 & 50 & 90 \\
\hline 26 & S-26 & 60 & 70 & 90 \\
\hline 27 & S-27 & 40 & 40 & 40 \\
\hline \multirow[t]{3}{*}{28} & S-28 & 50 & 50 & 90 \\
\hline & JUMLAH & 1520 & 1730 & 2010 \\
\hline & RATA - RATA & 54,2 & 61,7 & 71,7 \\
\hline
\end{tabular}

Tabel 7. Rata-rata Pencapaian Prestasi Siswa Setiap Siklus

\begin{tabular}{ccc}
\hline Siklus I & Siklus II & Siklus III \\
\hline 54,2 & 61,7 & 71,7 \\
\hline
\end{tabular}

Dari tabel di atas dapat dijelaskan bahwa rata-rata hasil kemampuan siswa siklus I, adalah 54,2 Siklus 2 meningkat menjadi 61,7 dan pada siklus 3, naik menjadi 71,7 sehingga ada peningkatan.

Tabel 8. Rata-Rata Keberhasilan Tindakan dari Aspek Guru

\begin{tabular}{ccc}
\hline Siklus I & Siklus II & Siklus III \\
\hline 36 & 69,2 & 77 \\
\hline
\end{tabular}

Dari tabel diatas dapat disimpulkan bahwa keberhasilan tindakan yang dicapai dari aspek guru untuk siklus 1 adalah $37 \%$, pada siklus 2 naik $69,2 \%$ dan pada siklus 3 meningkat menjadi $77 \%$.

\section{Pembahasan}

Berdasarkan hasil observasi ada 9 indikator yang belum berhasil. Dalam siklus 1 Sehingga dapat dikatakan bahwa keberhasilan guru baru 4 indikator dari 13 indikator yang direncanakan, atau $36 \%$.

Sedangkan berdasarkan hasil observasi terhadap siswa menunjukkan bahwa nilai ratarata yang dicapai siswa adalah 54,2 Nilai tertinggi yang dicapai siswa adalah 8 , dan nilai 
terendah yang dicapai siswa adalah 3. Siswa yang mendapat nilai dibawah 7 sejumlah 21 siswa yakni $75 \%$, Yang mencapai nilai 6 keatas sejumlah 7 siswa yakni $25 \%$.

Hal ini sesuai dengan the Liang Gia ( 1989, hal. 15 ) Mengatakan bahwa: Prestasi belajar adalah hasil yang dicapai aktifitas yang menghasilkan perubahan-perubahan tingkah laku dalam individu, baik secara aktual maupun profesional ". Berdasarkan hal tersebut maka, dapat di analisis dari proses pembelajaran yang dilaksanakan bahwa pencapaian prestasi tidak hanya dinilai dari nilai prestasi tes tetapi juga harus di lihat sisi lain dari perubahan prilaku dan perubahan sikap yang dimiliki oleh siswa. Jika dilihat dari data observasi menunjukan bahwa prilaku siswa dengan pencapaian prestasi adalah linier.

Berdasarkan hasil diskusi pada siklus 2 ada 5 indikator yang belum berhasil dalm proses pembelajarn Sehingga dapat dikatakan bahwa keberhasilan guru baru 9 indikator dari 13 indikator yang direncanakan, atau 69,2\%.

Dan nilai rata-rata yang dicapai siswa adalah 61,7 . Nilai tertinggi yang dicapai siswa adalah 9, sedangkan nilai terendah yang dicapai siswa adalah 3. Siswa yang mendapat nilai dibawah 70 sejumlah 11 orang yakni $39,29 \%$, yang mencapai nilai $70 \mathrm{ke}$ atas sejumlah 17 atau $60,71 \%$.

Sedangkan Purwodarminto ( 1987, hal. 254 ), mengatakan bahwa " prestasi belajar adalah suatu hasil yang dicapai atau dikerjakan siswa dalam belajar atau usaha untuk memperoleh suatu kepandaian ". Dengan usaha yang maksimal dari siswa untuk memperoleh kepandaian maka jelaslah bahwa dari siklus 1 telah mengalami perubahan prilaku dan sikap dalam belajar sehingga secara konsekwensi maka terjadi perubahan prestasi belajar.

Berdasarkan hasil refleksi pada siklus 3 diketahui bahwa dalam proses pembelajaran menggunakan metode bervariasi ada 3 indikator yang belum berhasil dengan baik tetapi sudah terlaksana. Dari data yang dihimpun dari observasi pengamat didapatkan bahwa keberhasilan guru baru 10 indikator dari 13 indikator yang direncanakan, atau $77 \%$.

Berdasarkan observasi didapatkan nilai rata-rata yang dicapai sisa adalah 71,7. Nilai tertinggi yang dicapai siswa adalah 9 . Sedangkan nilai terendah yang dicapai siswa adalah 4 . Siswa yang mendapat nilai dibawah 70 sejumlah 5 siswa yakni $17,85 \%$, yang mencapai nilai 70 ke atas sejumlah 23 siswa atau 82,12\%.

Hal ini sangat sesuai dengan penelitian yang dilakukan Soegito dan Nurani (2002), bahwa penggunaan metode mengajar yang bervariasi dapat meningkatkan minat siswa untuk mengikuti pelajaran, sehingga akan meningkatkan prestasi belajar.

\section{SIMPULAN DAN SARAN Simpulan}

Berdasarkan data analisis dan pembahasan maka dapat disimpulkan bahwa (1) Proses kegiatan setiap siklus, perlu refleksi yang optimal agar perencanaaan pada kegiatan berikuntnya berjalan sesuasi harapan; (2) Prestasi Belajar Mata Pelajaran Matematika Siswa SDN 2 Seponti Jaya Kelas 1 semester II dapat ditingkatkan melalui metode Bervariasi.

\section{Saran}

Berdasarkan hasil temuan dan perbaikan pembelajaran dengan menggunakan metode bervariasi maka disarankan : (1) Kepala sekolah hendaknya memberikan pembinaan kepada guru guru bidang eksakta unutuk mempertimbangkan penggunaan metode bervariasi. (2) Bagi guru bidang studi Matematika untuk dapat menggunakan metode bervariasi dan disesuaikan dengan materi yang akan disampaikan. (3) Bagi teman sejawat sebagai observer yang akan melaksanakan penelitian hendaknya lebih memperhatikan ketelitian dalam penyusunan langkah langkah dalam prosedur penelitian tindakan kelas.

\section{DAFTAR PUSTAKA}

Departemen Pendidikan Nasional, 2003 "Kurikulum Berbasis Kompetensi Mata Pelajaran Matematika SD dan Madrasah Ibtidaiyah. Jakarta: Kemendikbud.

Dinas Pendidikan dan Kebudayaan, (2002). GBPP Mata Pelajaran Matematika. Jakarat: Kemendikbud.

Karso Dkk, (2003). Pendidikan Matematika I. Jakarta: Universitas Terbuka.

Usman, Moh. Uzer \& Lilis Setiyawati, (1993). Upaya Optimalisasi Kegiatan Belajar Mengajar Bandung: PT Remaja Rosdakarya.

Wardini,Julaeha \& Marsinah Ngadi. (2004). Pemantapan Kemampuan Profesional (Panduan). Jakarta: Universitas Terbuka. 